\title{
$\beta$-Catenin is involved in alterations in mitochondrial activity in non-transformed intestinal epithelial and colon cancer cells
}

\author{
M Mezhybovska', Y Yudina', A Abhyankar ${ }^{2}$ and A Sjölander*,I \\ 'Cell and Experimental Pathology, Department of Laboratory Medicine, Malmö University Hospital, Lund University, Malmö, SE-205 02 , Sweden; \\ ${ }^{2}$ Department of Clinical Sciences, Clinical Research Centre, Malmö University Hospital, Lund University, Malmö, SE-205 02 , Sweden
}

\begin{abstract}
BACKGROUND: Alteration in respiratory activity and mitochondrial DNA (mtDNA) transcription seems to be an important feature of cancer cells. Leukotriene $\mathrm{D}_{4}\left(\mathrm{LTD}_{4}\right)$ is a proinflammatory mediator implicated in the pathology of chronic inflammation and cancer. We have shown earlier that $\mathrm{LTD}_{4}$ causes translocation of $\beta$-catenin both to the mitochondria, in which it associates with the survival protein $\mathrm{Bcl}-2$ identifying a novel role for $\beta$-catenin in cell survival, and to the nucleus in which it activates the TCF/LEF transcription machinery.

METHODS: Here we have used non-transformed intestinal epithelial Int 407 cells and Caco-2 colon cancer cells, transfected or not with wild type and mutated (S33Y) $\beta$-catenin to analyse its effect on mitochondria activity. We have measured the ATP/ADP ratio, and transcription of the mtDNA genes ND2, ND6 and $16 \mathrm{~s}$ in these cells stimulated or not with $\mathrm{LTD}_{4}$.

RESULTS: We have shown for the first time that LTD 4 triggers a cellular increase in NADPH dehydrogenase activity and ATP/ADP ratio. In addition, $\mathrm{LTD}_{4}$ significantly increased the transcription of mtDNA genes. Overexpression of wild-type $\beta$-catenin or a constitutively active $\beta$-catenin mutant mimicked the effect of $\mathrm{LTD}_{4}$ on ATP/ADP ratio and mtDNA transcription. These elevations in mitochondrial activity resulted in increased reactive oxygen species levels and subsequent activations of the p65 subunit of NF- $\kappa \mathrm{B}$. CONCLUSIONS: The present novel data show that $\mathrm{LTD}_{4}$, presumably through $\beta$-catenin accumulation in the mitochondria, affects mitochondrial activity, lending further credence to the idea that inflammatory signalling pathways are intrinsically linked with potential oncogenic signals.

British Journal of Cancer (2009) I 0I, I596- 1605. doi:I0.1038/sj.bjc.6605342 www.bjcancer.com

Published online 13 October 2009

(c) 2009 Cancer Research UK
\end{abstract}

Keywords: $\beta$-catenin; mitochondrial activity; mtDNA transcription; epithelial cells; colon cancer; leukotriene D4

Leukotriene $\mathrm{D}_{4}\left(\mathrm{LTD}_{4}\right)$ is a powerful proinflammatory mediator derived from arachidonic acid through the 5-lipoxygenase pathway. Arachidonic acid is the common precursor of a group of mediators collectively called eicosanoids (Funk, 2001). Leukotriene $\mathrm{D}_{4}$ is the most potent of the cysteinyl leukotrienes $\left(\mathrm{LTC}_{4}, \mathrm{LTD}_{4}\right.$, and $\mathrm{LTE}_{4}$ ). Leukotriene $\mathrm{D}_{4}$ is known to mediate its effects through specific cell surface receptors belonging to the $\mathrm{G}$ protein-coupled receptor family. The CysLT ${ }_{1}$ and CysLT $\mathrm{T}_{2}$ receptors has been most studied (Heise et al, 2000; Lynch et al, 1999; Sarau et al, 1999) of which, the $\mathrm{CysLT}_{1}$ receptor has been proven to have a much higher affinity for $\mathrm{LTD}_{4}$ (Heise et al, 2000). Leukotriene $\mathrm{D}_{4}$ signalling has been implicated in chronic inflammatory conditions such as asthma and inflammatory bowel diseases (IBDs) (Drazen, 2002).

Inflammatory bowel diseases are associated with an increased incidence of neoplastic transformation (Ekbom et al, 1990), suggesting that there is a link between inflammation and cancer (Sheng et al, 1997). Furthermore, earlier studies have shown that colon cancer is underrepresented in a population of patients with ulcerative colitis, who where treated with non-steroidal anti-

*Correspondence: A Sjölander;

E-mail: anita.sjolander@med.lu.se

Received 26 January 2009; revised 17 July 2009; accepted 3 September 2009; published online 13 October 2009 inflammatory drugs (Smalley and DuBois, 1997). This suggests that inflammatory mediators, such as $\mathrm{LTD}_{4}$, could be essential factors in mediating the coupling between IBD and colon cancer.

In 1930, Warburg showed that some types of cancer cells are capable of constitutive upregulation of glucose metabolism, even in the presence of the abundant oxygen. This phenomenon is known as the Warburg effect (Warburg, 1956). Cancer cells synthesise ATP mainly through 'anaerobic glycolysis', a metabolic state that is linked to high glucose uptake and local acidification due to lactate production, even in the presence of oxygen. Cancer cells often upregulate glycolysis enzymes as a result of constitutive signalling through the Akt pathway, or because of the expression of oncogenes such as Ras or Src (Elstrom et al, 2004; Pelicano et al, 2006). Earlier we have shown that $\mathrm{LTD}_{4}$ induces Akt phosphorylation in Int 407 cells (Paruchuri et al, 2005).

A major finding in understanding increases in respiration is based on the well-established fact that there is an increase in the average of ATP/ADP ratio (Matsunaga et al, 1996). The stimulation of both respiration (oxidative phosphorylation) and glycolysis is presumably responsible for the rise in the ATP/ADP ratio, which begins almost simultaneously with the increase in respiration.

Certain types of chronic inflammation such as ulcerative colitis have long been associated with a high risk of cancer development (Coussens and Werb, 2002; Hussain et al, 2003). It is believed that increased free radical generation is one important mechanism that 
promotes the progression of chronic inflammation into malignant transformation (Hussain et al, 2003). Cancer patients commonly have decreased glucose clearance capacity, high glycolytic activity and raised lactate production. Therefore, it has been suggested that the observed pro-oxidative shift is mediated by an increased availability of mitochondrial energy substrate. The inflammatory oxidative conditions' are typically associated with an excessive stimulation of $\mathrm{NAD}(\mathrm{P}) \mathrm{H}$ oxidase by cytokines and other inflammatory mediators (Kohli et al, 2007). Increased reactive oxygen species (ROS) production or changes in intracellular glutathione levels are often involved with pathological changes, both of which are indicative of signal cascade, or gene expression dysregulation (Waris and Ahsan, 2006).

$\beta$-Catenin is a multifunctional protein, its function is altered in most colon cancers. In non-transformed cells it is present at the cell membrane, where together with E-cadherin forms part of the adherent-type junction (Conacci-Sorrell et al, 2002; Cullen et al, $2004)$. In the presence of a Wnt signal, $\beta$-catenin translocates to the nucleus in which it activates transcription factors of the TCF/LEF family (Korinek et al, 1997). $\beta$-Catenin has an essential role in normal cell physiology, which makes it an unsuitable target for antagonising with specific inhibitors or siRNA. We have shown earlier that $\beta$-catenin translocates to the nuclei of Int 407 cells after exposure to the pro-inflammatory mediator $\mathrm{LTD}_{4}$ (Mezhybovska et al, 2006). We also found that after $\mathrm{LTD}_{4}$ stimulation, $\beta$-catenin was present in mitochondria where it was associated with the anti-apoptotic protein, Bcl-2 (Mezhybovska et al, 2006). Here we further examine the effects of $\beta$-catenin on mitochondrial activity.

\section{MATERIALS AND METHODS}

\section{Constructs}

HA-wt- $\beta$-catenin ( $\beta$-cat wt, wild type) and HA-S33Y- $\beta$-catenin ( $\beta$-cat S33Y, constitutively active mutant) constructs were generously provided by $\mathrm{Dr}$ Ben-Zeev (Weizmann Institute of Science, Rehovot, Israel). The NF $\kappa \mathrm{B}-\mathrm{RE}$ luciferase construct was from Promega (Madison, WI, USA).

\section{Cell culture}

The non-transformed human intestinal epithelial cell line (Int 407) which shows typical epithelial morphology and growth, was isolated from jejunum and ileum of a human embryo of 2 months gestation (Henle and Deinhardt, 1957). Int 407 cells were cultured as a monolayer in Eagle's basal medium supplemented with $15 \%$ newborn calf serum. The colon cancer cell line Caco-2 was grown in Dulbecco's modified Eagle medium (Sigma Chemicals Co, St Louis, MO, USA) with $10 \%$ fetal bovine serum (Wikström et al, 2003). All media was supplemented with $2 \mathrm{~mm}$ L-glutamine, $55 \mathrm{IU} \mathrm{ml}^{-1}$ penicillin and $55 \mu \mathrm{g} \mathrm{ml}^{-1}$ streptomycin. The cell lines were cultured at $37^{\circ} \mathrm{C}$ in a humidified atmosphere with $5 \% \mathrm{CO}_{2}$. The cells were regularly tested to ensure the absence of mycoplasma contamination.

\section{Transfection}

Transfection was performed in complete medium for $24 \mathrm{~h}$ using PolyFect transfection reagent (Qiagen $\mathrm{GmbH}$, Hilden, Germany), according to the manufacturer's instructions. In all transfection experiments it was routinely confirmed that empty vector had no effect.

\section{Reverse transcription - PCR}

Messenger RNA (mRNA) for the p65 NF- $\kappa$ B subunit was synthesised using the forward primer: GCGAGAGGAGCACAGAT ACCACCAA and the reverse primer: GGCAGATCTTGAGCTCGG CAGTGTT.

\section{mRNA isolation cDNA synthesis and quantitative real-time} PCR

Messenger RNA was isolated using the RNeasy Plus Mini Kit from Qiagen following the manufacturer's instructions. Complementary DNA (cDNA) was synthesised using the Fermentas Revert Aid $\mathrm{H}$ Minus First Strand cDNA Synthesis kit following the manufacturer's instructions, or with random hexamer primers and superscript II reverse transcriptase (Invitrogen, Carlsbad, CA, USA), according to the standard procedures. Complementary DNA was used as a template in quantitative real-time PCR reactions with TaqMan Gene Expression Assay (Applied Biosystems, Cambridge, UK) and Maxima Probe qPCR Mastermix (Fermentas Life Sciences, Vilnius, Lithuania). For relative quantification of expression levels, the comparative $C_{\mathrm{t}}$ method was used. The point at which the fluorescence crosses the threshold was taken as the $\left[C_{t}\right]$ value. Expression levels of the different genes of interest were normalised to the expression level of the housekeeping gene, $\beta$-actin or GAPDH.

\section{NADPH activity determination (MTS assay)}

Cells were grown to $60 \%$ confluency. They were then stimulated or not with $40 \mathrm{nM} \mathrm{LTD}_{4}$ for the indicated period of times. Assays were performed using the Cell Titer 96 assay kit from Promega, following the manufacture's instructions. Conversion of MTS (3-(4,5-dimethylthiazol-2-yl)-5-(3-carboxymethoxyphenyl)-2-(4-sulfophenyl)-2H-tetrazolium) into aqueous, soluble formazan was measured by recording absorbance at $490 \mathrm{~nm}$ using a 96-well plate reader.

\section{ATP/ADP ratio determination}

The transfected and untransfected cells were grown to $60 \%$ confluency, and thereafter stimulated or not with $40 \mathrm{~nm} \mathrm{LTD}_{4}$. Cells were collected in 20\% TCA and frozen on dry ice for ATP determination. ATP was determined using the ATP Kit SL (luminescent assays) from BioThema (Handen, Sweden). Untreated samples were diluted 40 -fold and measured bioluminometrically. Thereafter, ATP was irreversibly converted to AMP with ATP sulfurylase in the presence of molybdate. In all, $20 \mu \mathrm{l}$ of sample were mixed with $180 \mu \mathrm{l}$ of Buffer I $(50 \mathrm{~mm} / 5 \mathrm{~mm}$ Tris- $\mathrm{HCl} /$ $\mathrm{MgCl}_{2}, \mathrm{pH} 8.0,10 \mathrm{mM} \mathrm{Na}_{2} \mathrm{MoO}_{4}, 2.5 \mathrm{mM} \mathrm{GMP}$, and 0.5 U ATP sulfurylase), incubated for $20 \mathrm{~min}$ at $30^{\circ} \mathrm{C}$, boiled for $2.5 \mathrm{~min}$ and chilled on ice. Samples were diluted with $800 \mu \mathrm{l}$ milliQ-water and ATP was measured bioluminometrically. ADP was converted to ATP by pyruvate kinase. In total, $100 \mu \mathrm{l}$ of the diluted sample from the previous step was mixed with $100 \mu \mathrm{l}$ of the Buffer II $(50 \mathrm{~mm} /$ $5 \mathrm{~mm}$ Tris- $\mathrm{HCl} / \mathrm{MgCl}_{2}, \mathrm{pH} 8.0,38 \mathrm{~mm} \mathrm{KCl}, 0.5 \mathrm{~mm}$ phosphopyruvate, and $50 \mathrm{U}$ pyruvate kinase), samples were incubated at room temperature for $30 \mathrm{~min}$. To terminate the reaction $300 \mu \mathrm{l}$ of $\mathrm{H}_{2} \mathrm{O}$ was added and ATP was measured bioluminometricaly (Lundin, 2000). ADP was calculated as the difference between the ATP measured after incubation with pyruvate kinase, and the residual ATP measured after treatment with sulfurylase alone.

\section{Transient transfection and luciferase assays}

Luciferase assays were carried out using the Dual Luciferase Reporter Assay System from Promega. Each plasmid was used at a final concentration of $1 \mu \mathrm{g} \mathrm{ml}^{-1}$, except for the control Renilla luciferase vector, which was always used at $0.2 \mu \mathrm{g} \mathrm{ml}^{-1}$ to standardise for transfection efficiency. Vector DNA was allowed to form complexes with PolyFect. Cells in 12-well plates were washed once in serum-free medium, and the DNA-Polyfect mixture was added. Cells were transfected at $37^{\circ} \mathrm{C}$ for $24 \mathrm{~h}$ in complete medium, after which the medium was changed to normal growth medium, and the cells allowed to recover for $24 \mathrm{~h}$. Before 
any further stimulation, the cells were left in serum-free medium for $1 \mathrm{~h}$. The cells were then pre-treated or not with $30 \mu \mathrm{M} \mathrm{NAC}$ (N-acetyl-L-cysteine, Sigma Chemicals Co, an antioxidant capable of neutralising ROS) for $15 \mathrm{~min}$ and then incubated in the absence or presence of $40 \mathrm{nM} \mathrm{LTD}_{4}$ for the indicated period of time. After stimulation with $\mathrm{LTD}_{4}$, cells were washed in PBS and lysed using $250 \mu \mathrm{lwell}^{-1}$ of the DLR passive lysis buffer provided in the assay. Lysed samples were collected and briefly centrifuged to precipitate the debris. A $20 \mu \mathrm{l}$ volume of each lysate was used to measure luciferase activity with $50 \mu \mathrm{l}$ luciferase assay substrate using a MiniLumat LB 9506 (Berthold Technologies, Hannover, Germany) luminometer. The control Renilla luciferase signal was recorded after the subsequent addition of $50 \mu \mathrm{l}$ of Stop\&Glow buffer, and the level of expression given as a ratio. In every experiment, triplicate samples were prepared and analysed for each condition.

\section{Dihydroethidium staining}

The oxidative fluorescent dihydroethidium (DHE) dye was used to evaluate the intracellular production of $\mathrm{O}_{2}^{-} \bullet$ (Kitada et al, 2003). Dihydroethidium is cell permeable and reacts with $\mathrm{O}_{2}^{-} \bullet$ to form ethidium, which in turn intercalates with DNA, providing nuclear fluorescence at an excitation wavelength of $520 \mathrm{~nm}$ and emission wavelength of $610 \mathrm{~nm}$. The cells were grown to $60 \%$ confluency, and were transfected with HA-S33Y- $\beta$-catenin or HA-wt- $\beta$ catenin. After $24 \mathrm{~h}$, the cells were serum starved overnight and the following day incubated with $50 \mu \mathrm{M}$ DHE at $37^{\circ} \mathrm{C}$ for $30 \mathrm{~min}$. Then the cells were washed with PBS and serum-free culture media was added before fluorescent microscopy (Kohli et al, 2007). Exogenous addition of $\mathrm{H}_{2} \mathrm{O}_{2}$ was used as a positive control. All images shown are of living cells maintained under physiological conditions by fluorescent microscopy using an Olympus microscope IX81 (Hamburg, Germany), objective $\times 20$.

\section{Western blot}

The cells were lysed and scraped loose with ice-cold lysis buffer (50 mu Tris, pH 7.5, 1 mm EDTA, 1 mm EGTA, $1 \mathrm{~mm} \mathrm{Na}_{3} \mathrm{VO}_{4}, 1 \%$ Triton X-100, $50 \mathrm{~mm} \mathrm{NaF}, 5 \mathrm{~mm}$ sodium pyrophosphate, $10 \mathrm{~mm}$ sodium glycerophosphate, $4 \mu \mathrm{g} \mathrm{ml}^{-1}$ leupeptin, and $30 \mu \mathrm{g} \mathrm{ml}^{-1}$ phenylmethanesulfonyl fluoride (PMSF)). The resultant lysate was boiled with sample buffer (62 mM Tris $\mathrm{pH} 6.8,1.0 \%$ SDS, $10 \%$ glycerol, $15 \mathrm{mg} \mathrm{ml}^{-1}$ dithiothreitol, and $0.05 \%$ bromphenol blue) for $10 \mathrm{~min}$. Equal amounts of protein $\left(30-50 \mu \mathrm{g}\right.$ protein well $\left.{ }^{-1}\right)$ were loaded and subjected to electrophoresis on $8 \%$ homogeneous polyacrylamide gels. The separated proteins were electrophoretically transferred to PVDF membranes, which were then blocked for $1 \mathrm{~h}$ at ambient temperature with 3\% BSA/PBS. The membranes were then incubated overnight at $4{ }^{\circ} \mathrm{C}$ with the primary antibody ( $\beta$-catenin diluted 1:500). The membranes were washed and incubated for $1 \mathrm{~h}$ with HRP-conjugated secondary antibody, diluted 1:5000 in 3\% BSA/PBS with 0.1\% Tween-20. Membranes were incubated with ECL western blot detection reagents, and exposed to Hyperfilm-ECL to visualise immunoreactive proteins (Mezhybovska et al, 2006).

\section{Cell fractionation}

Treatments were terminated by the addition of ice-cold lysis buffer (20 mM NaHepes pH 8.0, $2 \mathrm{~mm} \mathrm{MgCl}_{2}, 1 \mathrm{~mm}$ EDTA, $5 \mathrm{~mm}$ orthovandate, $60 \mu \mathrm{g} \mathrm{ml}^{-1}$ PMSF and $4 \mu \mathrm{g} \mathrm{ml}^{-1}$ leupeptin) and the cells were placed on ice. After $\mathrm{N}_{2}$-decompression at 1000 psi for $10 \mathrm{~min}$ using a cell disruption bomb (Parr Instrument Company, Moline, IL, USA) and centrifugation at $200 \mathrm{~g}$, the supernatant was centrifuged at $10000 \mathrm{~g}$ for $10 \mathrm{~min}$, and further centrifugation at $200000 \mathrm{~g}$ for $1 \mathrm{~h}$, to obtain an isolated cytosolic fraction.

\section{RESULTS}

\section{Leukotriene $\mathrm{D}_{4}$ increases metabolic activity in mitochondria}

We have shown earlier that $\mathrm{LTD}_{4}$ increases cell survival and causes translocation of $\beta$-catenin to mitochondria. Therefore, we analysed whether $\mathrm{LTD}_{4}$ could affect mitochondrial activity. We observed a significant increase in the NADPH dehydrogenase activity in both the non-transformed epithelial cell line Int 407 and the cancer cell line Caco-2 (Figures $1 \mathrm{~A}$ and $\mathrm{B}$ ) in response to the $\mathrm{LTD}_{4}$ stimulation $(40 \mathrm{nM})$. The maximum effect was reached after $15 \mathrm{~min}$ of stimulation with a significant increase after $1 \mathrm{~h}$. The activity declined again after $2 \mathrm{~h}$ of stimulation. As a consequence of increased metabolism in the cell, an increase in the ATP/ADP ratio occurs, which contributes to plasma membrane depolarisation followed by activation of calcium channels leading to an increase in intracellular calcium (Fridlyand et al, 2005). Leukotriene $\mathrm{D}_{4}$ increased intracellular calcium levels in both Int 407 and Caco-2 cells (Nielsen et al, 2005). We also found an increase in the ATP/ ADP ratio that was delayed compared with NADPH dehydrogenase activity, with a maximum effect after $1 \mathrm{~h}$. The change was statistically significant at time points between $15 \mathrm{~min}$ and $1 \mathrm{~h}$ of $\mathrm{LTD}_{4}$ stimulation in both cell lines (Figures $1 \mathrm{C}$ and D).

\section{Leukotriene $\mathrm{D}_{4}$ increases mitochondrial gene transcription}

Next, we examined whether $\mathrm{LTD}_{4}$ had any effect on mitochondrial gene transcription. The mitochondrial DNA (mtDNA) is present at a high copy number per cell. It contains genes encoding 13 polypeptides, essential for protein synthesis in mitochondria, and a non-coding region called the displacement loop (D-loop). The $\mathrm{D}$-loop is involved in the control of replication and transcription of mtDNA. The two mtDNA strands differ in their $\mathrm{G}+\mathrm{T}$ content and can therefore be separated into a heavy strand (H-strand), and a light strand (L-strand). In human cells each strand contains one single promoter for transcriptional initiation (Clayton, 1991; Ojala et al, 1981), and an additional initiation site for heavy strand transcription (Montoya et al, 1983). We chose to measure mRNA of one gene from each transcript of the two strands of the D-loop that control replication and transcription of mtDNA, in order to detect changes in mitochondrial-encoded gene activity. We observed a significant increase in mRNA for ND2 (NADH dehydrogenase subunit 2) both in Int 407 and Caco-2 cells (Figures 2A and B). This increase in transcription level occurred after $15 \mathrm{~min}$ of $\mathrm{LTD}_{4}$ stimulation, with the maximum three-fold increase observed after $2 \mathrm{~h}$ in Int 407 cells and after $1 \mathrm{~h}$ in Caco-2 cells. The same was seen in both cell lines for the other gene transcripts, ND6 (NADH dehydrogenase subunit 6) and $16 \mathrm{~s}$, with the maximum effect after $2 \mathrm{~h}$ stimulation with $40 \mathrm{nM} \mathrm{LTD}_{4}$ in Int 407 cells and $1 \mathrm{~h}$ for the Caco-2 cells (Figures 2C-E and F). The maximum increase (three-fold) was found for $16 \mathrm{~s}$ mRNA in Int 407 cells after $2 \mathrm{~h}$ of $\mathrm{LTD}_{4}$ treatment (Figure 2E).

\section{$\beta$-Catenin affects mitochondrial activity}

Int 407 is a non-transformed cell line showing epithelial cell morphology, in which $\beta$-catenin is mainly present at the sites of cell-cell junctions (i.e., at the plasma membrane) and follows a normal degradation pattern (Mezhybovska et al, 2005). The Caco-2 cell line, however, has a mutation in the APC gene. APC is a part of the $\beta$-catenin degradation complex. Caco- 2 cells have a nonfunctional $\beta$-catenin degradation pathway, leading to accumulation of $\beta$-catenin in the cells. As seen in Figure $3 \mathrm{~A}$, the endogenous level of $\beta$-catenin in the Caco- 2 cells is significantly higher than in Int 407 cells ( $12 \mu \mathrm{g}$ of total protein from Int 407 cells and $4 \mu \mathrm{g}$ from Caco-2 cells were loaded on the gel). Next we examined whether $\beta$-catenin affects mitochondrial activity. We have shown that 
A

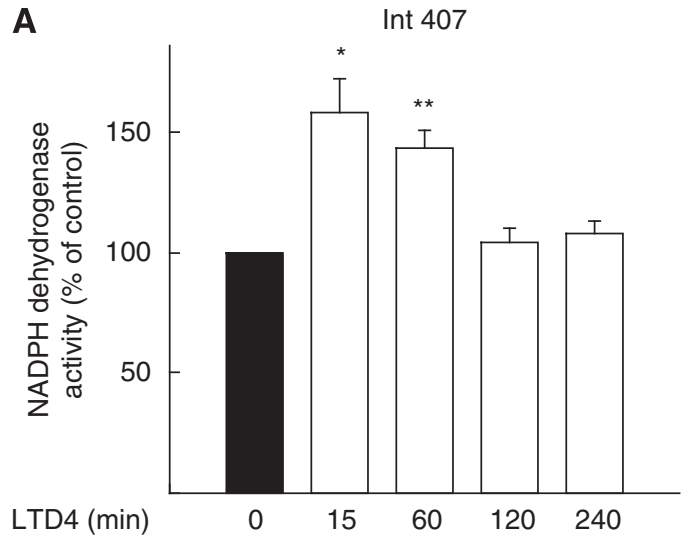

C

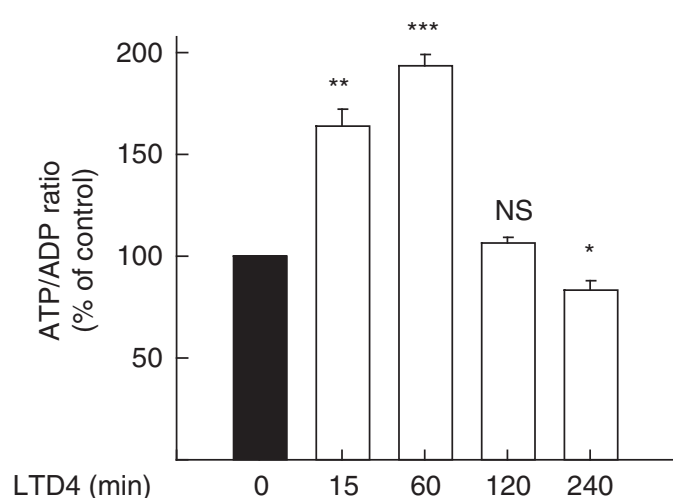

B

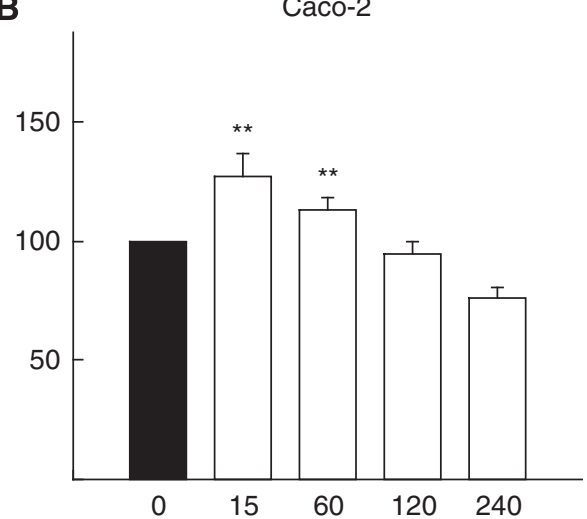

D

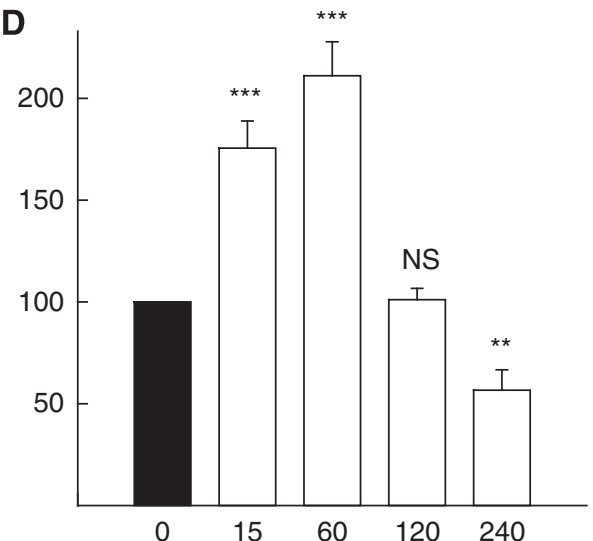

Figure I Leukotriene $\mathrm{D}_{4}\left(\mathrm{LTD}_{4}\right)$-induced increase in mitochondrial activity. Int 407 (A, C) and Caco-2 (B, D) cells were pre-incubated for indicated periods of time with $40 \mathrm{~nm} \mathrm{LTD}$. (A, B) Cells cultured in complete medium in 96-well plates were subjected to a MTS assay (NADPH dehydrogenase activity) according to the manufacturer's instructions. Conversion of MTS into aqueous soluble formazan was measured by recording the absorbance at $490 \mathrm{~nm}$ using a 96-well plate reader. (C, D) Cells were collected in 20\% TCA in PBS, and fast frozen. Thereafter, ATP and ADP amounts were measured as described in the Materials and Methods section. The presented data are given as means \pm s.e. of three separate experiments. $* P<0.05$; $* * P<0.01$; $* * * *<0.005$

$\beta$-catenin translocates to the mitochondria and interacts with the survival protein Bcl-2 (Mezhybovska et al, 2006). We overexpressed the following $\beta$-catenin constructs: $\beta$-cat wt and $\beta$-cat S33Y, and measured ATP/ADP ratio in the cells. It is worth mentioning that both $\beta$-catenin constructs are expressed equally in the cells (data not shown). Overexpression of both wild-type $\beta$-cat wt and mutant $\beta$-cat S33Y gave at least a 1.5 -fold increase in ATP/ ADP ratio in Int 407 cells (Figure $3 \mathrm{~B}$ ) and a 2.5 -fold increase in Caco-2 cells (Figure $3 \mathrm{C}$ ). This effect was almost totally dependent on the $\beta$-catenin-mediated stimulation of the mitochondrial activity and not on the increase of number of the mitochondria, as seen from Figure 1A. The increase in viable cell number after wt or S33Y $\beta$-catenin overexpression were $<0.2$-fold after $24 \mathrm{~h}$ $(118 \pm 11 \% \quad(w t)$ and $122 \pm 10 \% \quad(\mathrm{~S} 33 \mathrm{Y})$ of that seen after transfection with empty vector), which is $<15 \%$ of the total increase in ATP/ADP ratio. Interestingly, $\mathrm{LTD}_{4}$ stimulation of cells overexpressing the $\beta$-cat wt construct caused a further increase in ATP/ADP ratio compared with unstimulated cells. However, LTD $_{4}$ stimulation in cells overexpressing the $\beta$-cat S33Y construct did not cause any significant changes in mitochondrial activity (Figures 3B and C). The empty vector control had no effect.

The basal expression levels of mitochondrial-encoded genes were different between Int 407 and Caco- 2 cells. The basal levels of mitochondrial gene expression were significantly higher in Caco-2 cells (Table 1A). The difference in $\beta$-catenin levels in the two cell lines obviously correlated with the basal expression profiles of their mitochondrial-encoded genes.
In Int 407 cells, there was a dramatic increase in the expression levels of all three genes ND2, ND6 and $16 \mathrm{~s}$ after transfection with $\beta$-cat wt or $\beta$-cat S33Y (Table 1B). These stimulated levels in Int 407 cells were compatible to basal expression levels of Caco-2 cells. After the same treatment in Caco- 2 cells, the effect of $\mathrm{LTD}_{4}$ on gene activity was less prominent. Activity of the ND2 and ND6 genes was not significantly different from cells transfected with empty vector, but $16 \mathrm{~s}$ transcription was increased 1.5 -fold (Table $1 \mathrm{C}$ ). In the Int 407 cells that had been transfected with wild-type or mutant $\beta$-catenin, $\mathrm{LTD}_{4}$ stimulation induced a significant increase in ND2, ND6 and $16 \mathrm{~s}$ transcription. Stimulation of Caco-2 cells overexpressing wild-type $\beta$-catenin was not significantly different from the unstimulated cells for ND2, ND6 and $16 \mathrm{~s}$ expression. Stimulation of Caco- 2 cells that overexpressed constitutively active $\beta$-catenin, resulted in a significant increase compared with unstimulated cells (the effect was 1.5 -fold for all analysed genes). The difference in the response between Int 407 and Caco-2 cells to $\mathrm{LTD}_{4}$ stimulation might be explained by the substantial difference in basal levels of gene expression between the two cell lines (Table 1A).

\section{$\beta$-Catenin-mediated increase in mitochondria activity leads to NF- $\kappa$ B activation through ROS}

Oxidative phosphorylation is the main source of ROS production. Increased mitochondrial activity is expected to induce ROS production. As we observed earlier that $\mathrm{LTD}_{4}$ stimulation leads 
A

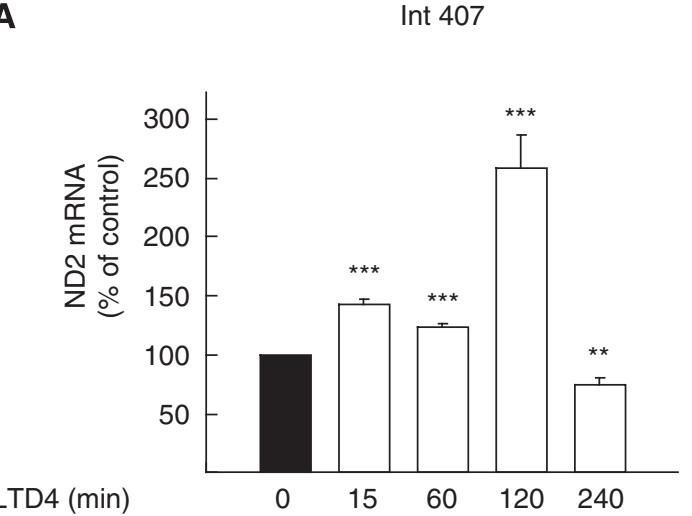

C

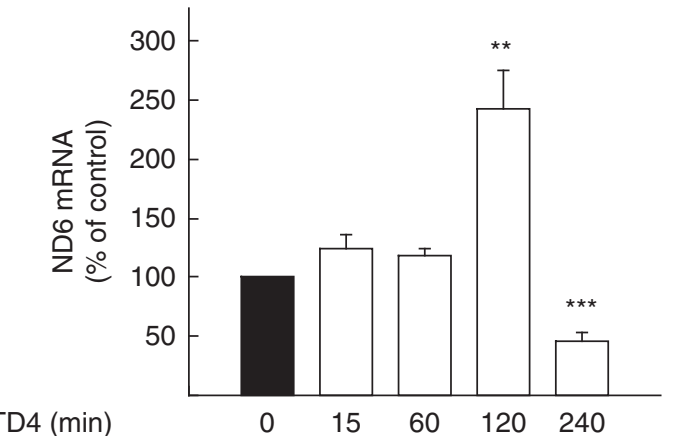

E

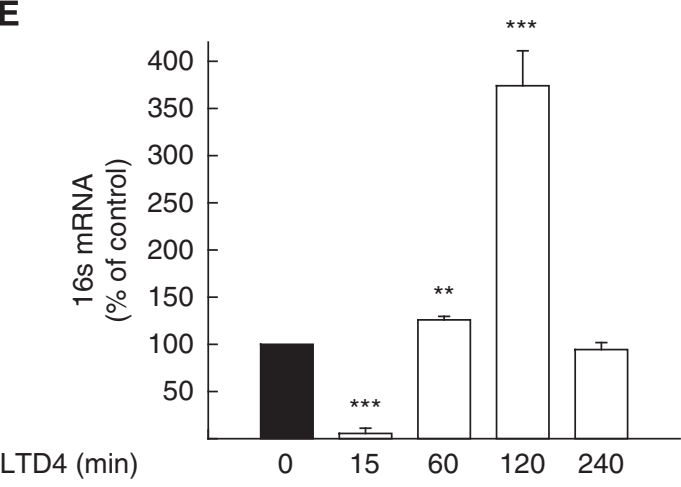

B
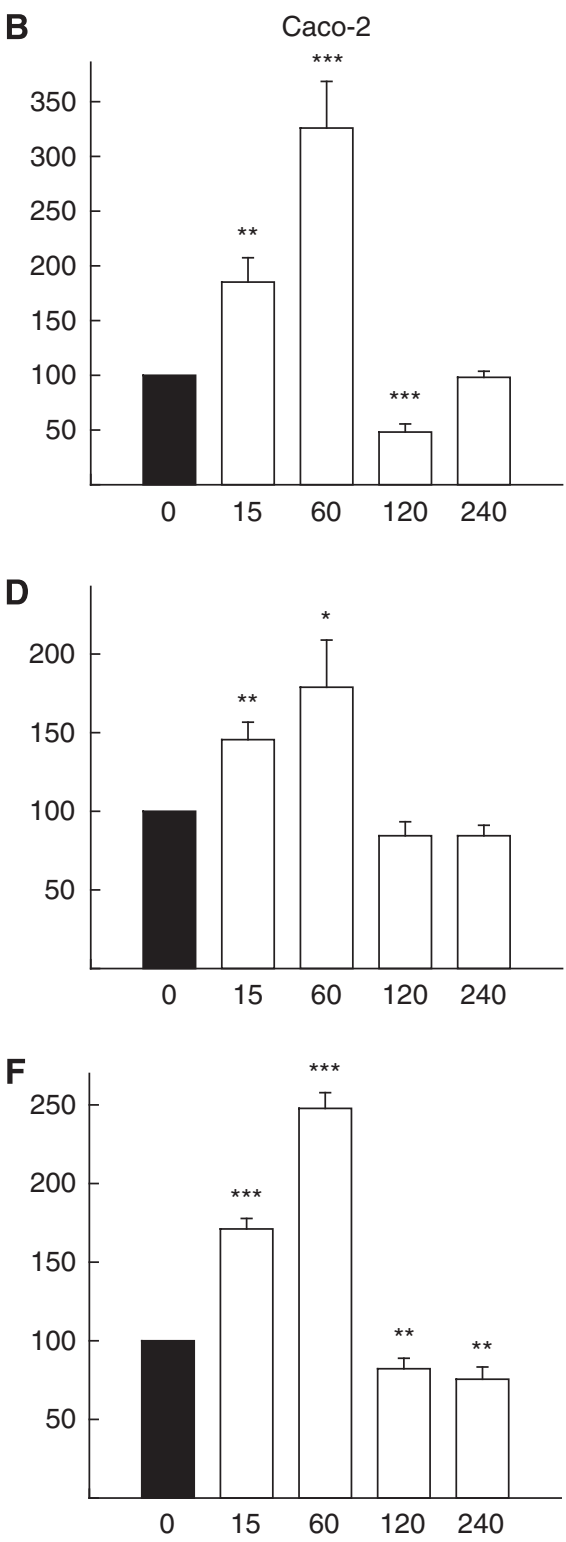

Figure 2 Expression of the mitochondrial-encoded genes upon leukotriene $\mathrm{D}_{4}\left(\mathrm{LTD}_{4}\right)$ stimulation. Levels of ND2 (A, B), ND6 (C, D), and I6s (E, F) messenger RNA (mRNA) in Int $407(\mathbf{A}, \mathbf{C}$, and $\mathbf{E})$ and Caco-2 (B, D, and $\mathbf{F})$ cells, were measured by real-time PCR after stimulation with $40 \mathrm{nM}$ LTD 4 for the indicated periods of time. Expression levels of the genes of interest were normalised to the expression of the reference gene $\beta$-actin. The presented data are given as means \pm s.e. of three separate experiments. ${ }^{*} P<0.05$; ${ }^{*} * P<0.0$ I; ${ }^{*} * * * 0.005$.

to an accumulation of $\beta$-catenin in mitochondria, we next examined whether $\mathrm{LTD}_{4}$ stimulation and $\beta$-catenin overexpression resulted in elevated levels of ROS. The mean fluorescence intensity value per cells for unstimulated empty vector was 11.2 relative units (RU), calculated by the image program ImageJ (W Burger \& MJ Burge, NIH, USA). Extracellular addition of $\mathrm{H}_{2} \mathrm{O}_{2}$ was used as a positive control (mean fluorescent intensity per cell was $26.5 \mathrm{RU}$ ). Leukotriene $\mathrm{D}_{4}$ increased ROS production in Int 407 cells, although the effect was less prominent than in the positive control (mean fluorescence per cell 16.1 RU; Figure 4). Overexpression of $\beta$-catenin constructs also caused an increase in ROS production. The downstream target for ROS in many cell types is the NF- $\kappa \mathrm{B}$ family of transcription factors (Bubici et al, 2006). We found that overexpression of $\beta$-catenin resulted in the activation of the p65 subunit of NF- $\kappa \mathrm{B}$ (Figures $5 \mathrm{~A}$ and $\mathrm{B}$ ). Furthermore, the p65 subunit mRNA of NF- $\kappa \mathrm{B}$ is increased in $\mathrm{LTD}_{4}$-stimulated cells. A similar increase was observed after overexpression of the $\beta$-cat wt or $\beta$-cat S33Y constructs. Leukotriene $\mathrm{D}_{4}$ stimulation of cells overexpressing $\beta$-cat wt or $\beta$-cat S33Y construct did not significantly change the level of the p65 mRNA (Figures 5A and B).

We next analysed whether $\mathrm{LTD}_{4}$ or $\beta$-catenin could affect the activity of NF- $\kappa \mathrm{B}$. After $\mathrm{LTD}_{4}$ stimulation, we detected a three-fold increase in the activity of NF- $\kappa \mathrm{B}$ responsive elements in Int 407 cells and a 1.5-fold increase in Caco-2 cells (Figures 5C and D). Overexpression of $\beta$-cat wt or $\beta$-cat S33Y significantly increased activity of NF- $\kappa$ B responsive elements in Int 407 (two-fold), and Caco- 2 cells (1.4-fold). To analyse whether the increase in NF- $\kappa \mathrm{B}$ activity was ROS mediated, we used an antioxidant to block ROS formation. Preincubation with $\mathrm{N}$-acetylcysteine (NAC) significantly reduced the effect of $\mathrm{LTD}_{4}$ and $\beta$-catenin overexpression in both cell lines (Figures 5C and D). We also analysed how NF- $\kappa \mathrm{B}$ activation affected its downstream target gene Bcl-2. Leukotriene $\mathrm{D}_{4}$ induced a significant increase in $\mathrm{Bcl}-2$ expression that was further increased in cells transfected with either wt $\beta$-catenin or 
A

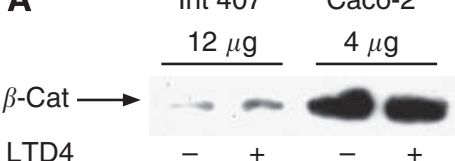

B

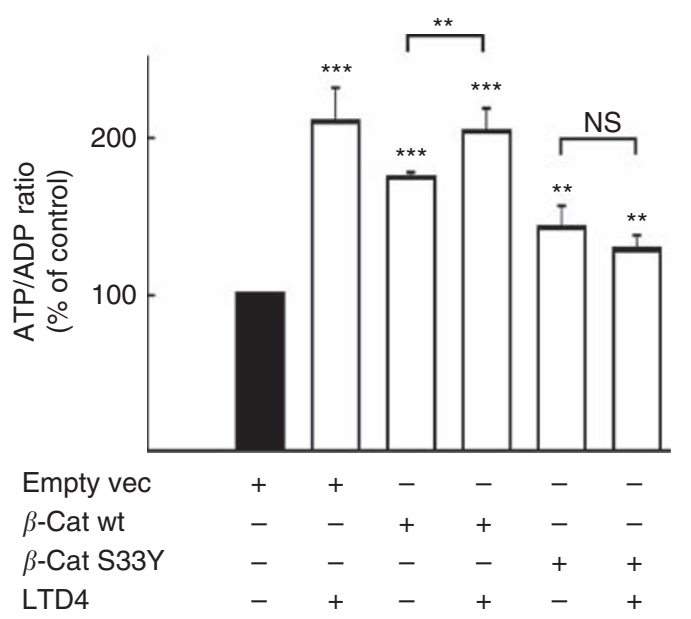

C

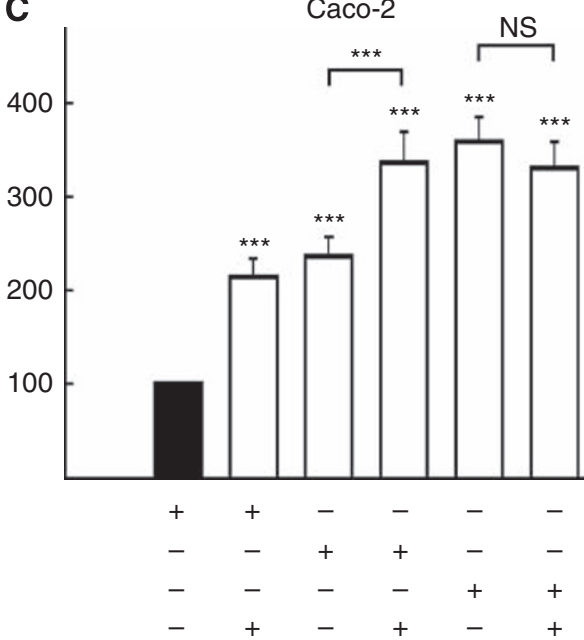

Figure 3 Overexpression of $\beta$-catenin increases ATP/ADP ratio. (A) The endogenous levels of $\beta$-catenin in Int 407 and Caco-2 cells cytosolic fractions. For the Caco-2 cells only one-third of total protein was added compared with the Int 407 cells, in order to evaluate the amount of $\beta$-catenin present in the cytosol. (B) Levels of overexpressed $\beta$-catenin HA-wt- $\beta$-catenin ( $\beta$-cat wt) and HA-S33Y- $\beta$-catenin $(\beta$-cat S33Y) mutant in Int 407 cells. Int 407 (C) and Caco-2 (D) cells were transiently transfected with empty vector (empty vec), $\beta$-cat wt or $\beta$-cat S33Y, and treated or not treated with $40 \mathrm{nM}$ LTD 4 for I h. Thereafter, cells were collected in 20\% TCA in PBS, and fast frozen. ATP and ADP amounts were measured as described in the Materials and methods section. The presented data are given as means \pm s.e. of four separate experiments. $* P<0.05 ; * * P<0.0$ I; $* * * P<0.005$.

Table I Overexpression of $\beta$-catenin increases mitochondria-encoded genes activity

\begin{tabular}{|c|c|c|c|}
\hline Gene & Int 407 (mean \pm s.e.) & Caco-2 (mean \pm s.e.) & \\
\hline Gene & Transfections & $\begin{array}{l}\text { Unstimulated } \\
\text { (mean } \pm \text { s.e.) }\end{array}$ & $\begin{array}{c}\text { Stimulated with } \text { LTD }_{4} \\
\text { (mean } \pm \text { s.e.) }\end{array}$ \\
\hline \multicolumn{4}{|c|}{ (B) Int 407 cells } \\
\hline ND2 & $\begin{array}{l}\text { Empty vec } \\
\beta \text {-cat wt } \\
\beta \text {-cat S33Y }\end{array}$ & $\begin{array}{c}100 \\
605.6 \pm 20.7 * * * * \\
804.1 \pm 47.6 * * * *\end{array}$ & $\begin{array}{l}353 \pm 14.4 * * \\
9937 \pm 207.2 * * * ; \\
3448.2 \pm \text { 123.8**; }\end{array}$ \\
\hline ND6 & $\begin{array}{l}\text { Empty vec } \\
\beta \text {-cat wt } \\
\beta \text {-cat S33Y }\end{array}$ & $\begin{array}{c}100 \\
183.3 \pm 6.9 * * * * \\
1 \mid 63 \pm 37.0 * * *\end{array}$ & 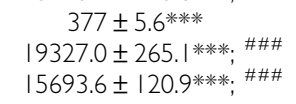 \\
\hline $16 \mathrm{~s}$ & $\begin{array}{l}\text { Empty vec } \\
\beta \text {-cat wt } \\
\beta \text {-cat S33Y }\end{array}$ & $\begin{array}{c}100 \\
255.0 \pm 6 * * * \\
371.3 \pm 7.8^{* * * *}\end{array}$ & $\begin{array}{c}163 \pm 4 * * \\
6294.3 \pm 68 * * * ; \# \# \# \\
2804.6 \pm 43.7 * * * ;\end{array}$ \\
\hline ND6 & $\begin{array}{l}\text { Empty vec } \\
\beta \text {-cat wt } \\
\beta \text {-cat S33Y }\end{array}$ & $\begin{array}{c}100 \\
89.3 \pm 7.0 \\
191.6 \pm 12.4 * *\end{array}$ & $\begin{array}{l}135.6 \pm 7.7 * * * \\
91.6 \pm 5.6 \\
\mid 91.4 \pm 11.4 * *\end{array}$ \\
\hline $16 \mathrm{~s}$ & $\begin{array}{l}\text { Empty vec } \\
\beta \text {-cat wt } \\
\beta \text {-cat S33Y }\end{array}$ & $\begin{array}{c}100 \\
148 \pm 9.2 * * \\
199 \pm 12 * *\end{array}$ & $\begin{array}{c}137 \pm 6.9 * * \\
155.3 \pm 10^{* *} \\
314 \pm 11 \text { *** }\end{array}$ \\
\hline
\end{tabular}

Levels of ND2, ND6, and 16s mRNA in Int 407 and Caco-2 cells were measured after 5 days of cell growth, transfection was performed on the forth day in complete growth medium. Thereafter, cells were stimulated or not for $1 \mathrm{~h}$ with $40 \mathrm{nM} \mathrm{LTD}$. The expression of the genes of interest were normalised to the expression of the housekeeping gene actin B. The presented data are given as means \pm s.e. of four separate experiments. First, we compared $\beta$-catenin constructs transfections and stimulations with unstimulated empty vector control for each gene, $* P<0.05$; $* * P<0.0$; ${ }^{*} * * P<0.005$. Second, we compared stimulated with $L_{T} D_{4}$ to unstimulated for each vector transfection, ${ }^{\# \# \# P<0.005}$ 


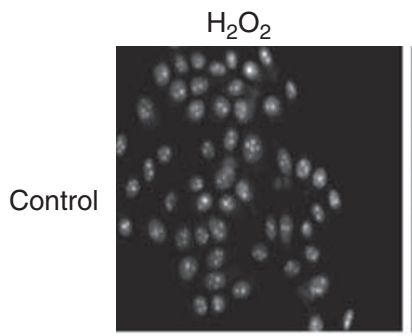

Empty vec
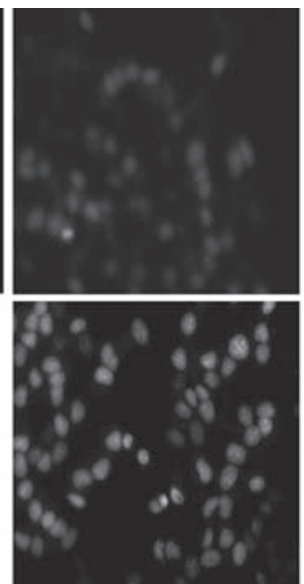

$\beta$-Cat wt
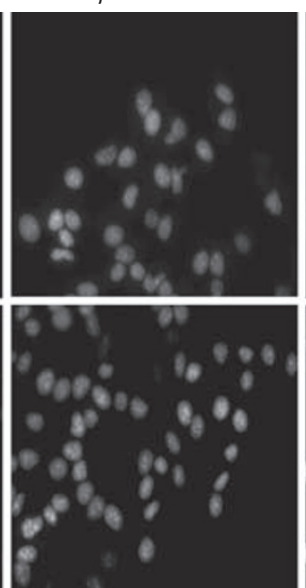

$\beta$-Cat S33Y

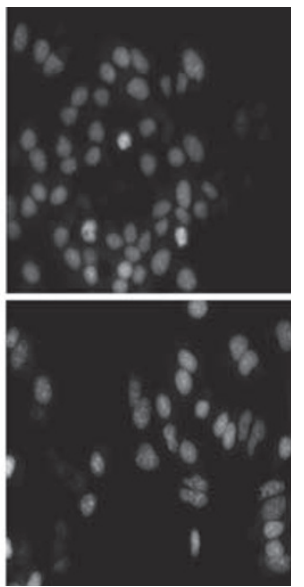

Figure 4 Detection of $\mathrm{O}_{2}^{-} \bullet$ production by dihydroethidium (DHE) staining in Int 407 cells. Representative results of DHE staining are shown from three independent experiments Int 407 cells (with or without overexpression of HA-wt- $\beta$-catenin ( $\beta$-cat wt) or HA-S33Y- $\beta$-catenin) stimulated or not with 40 nM $\mathrm{LTD}_{4}$ for I $\mathrm{h}$. The mean fluorescent intensity per cell in empty vector transfected cells was I I.2 RU, the mean value per cell for $\mathrm{H}_{2} \mathrm{O}_{2}$ positive control 26.5 $\mathrm{RU}$, and for the $\mathrm{LTD}_{4}$ stimulation in Int 407 cells was I6.I RU, mean values for other treatments were not different from $\mathrm{LTD}_{4}$ stimulation. Before imaging, the cells were preincubated with DHE for $30 \mathrm{~min}$. The fluorescent micrographs show living cells under physiological conditions with $20 \times$ objective.

A

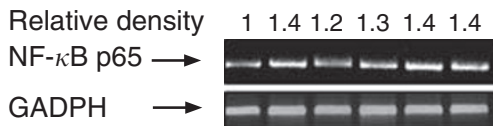

\section{Empty vec}

$\beta$-Cat wt

$\beta$-Cat S33Y

LTD4
Int 407

$$
\begin{array}{cccccc}
+ & + & - & - & - & - \\
- & - & + & + & - & - \\
- & - & - & - & + & +
\end{array}
$$$$
-+-+-+
$$

\section{B Caco-2}

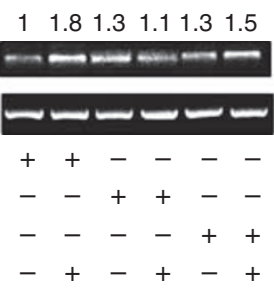

C

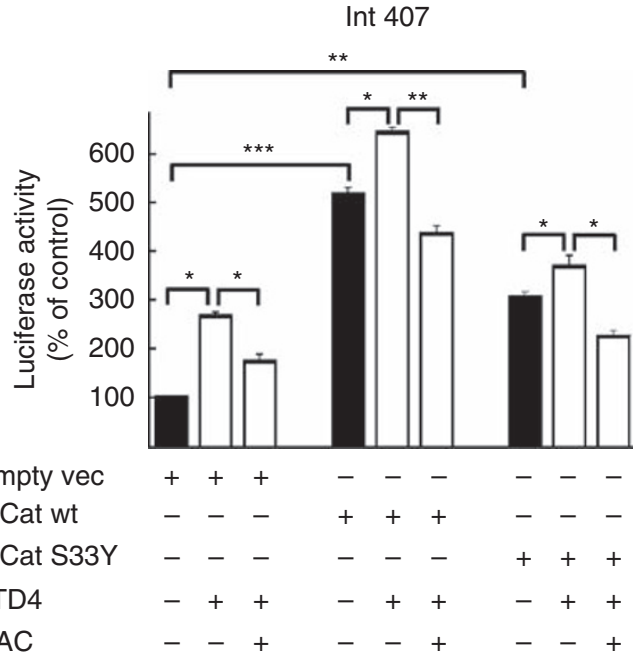

D

Caco-2

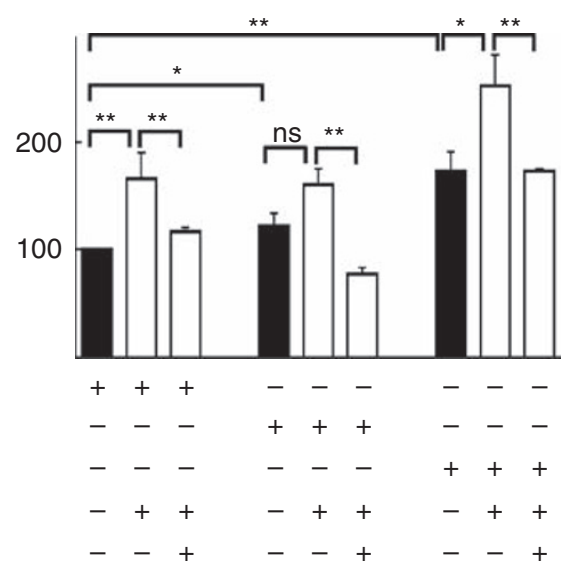

Figure 5 Activation of the p65 subunit of NF- $\kappa$ B and the NF- $\kappa$ B response element in cells overexpressing $\beta$-catenin. Int 407 (A, C) and Caco-2 (B, D) cells were transiently transfected with empty vector (empty vec), HA-wt- $\beta$-catenin ( $\beta$-cat wt) or HA-S33Y- $\beta$-catenin ( $\beta$-cat S33Y), and treated or not treated with $40 \mathrm{~nm}$ leukotriene $\mathrm{D}_{4}\left(\mathrm{LTD}_{4}\right)$ for I h. PCR was performed to estimate levels of p65 messenger RNA (mRNA) (A, B). The results shown are representative of three separate experiments. In $(\mathbf{C})$ and $(\mathbf{D})$ cells were transiently co-transfected with NF $\kappa$ B-luc and Renilla, plus one of the following vectors: empty vector (empty vec), $\beta$-cat wt or $\beta$-cat S33Y. As indicated, the cells were the pre-treated or not with NAC for I 5 min before incubation in the absence or presence of $40 \mathrm{nM} \mathrm{LTD}$ for I h. The luciferase values were measured and normalised to the Renilla values. The present data are given as means \pm s.e. of three separate experiments. $* P<0.05 ; * * P<0.0$ I; $* * * P<0.005$.

the S33Y- $\beta$-catenin mutant (Figures 6A). These effects of $\mathrm{LTD}_{4}$ were totally dependent on the $\mathrm{LTD}_{4}$-induced ROS production as shown by the use of the ROS inhibitor NAC that totally blocked the $\mathrm{LTD}_{4}$-induced increase in Bcl-2 expression (Figure 6A). To show the specificity of ROS/NF- $\kappa \mathrm{B}$ activation we also analysed the wellknown target gene of $\beta$-catenin/TCF activity Cyclin D1. We found that both $\mathrm{LTD}_{4}$ and $\beta$-catenin overexpression significantly increased Cyclin D1 expression (Figure 6B). In contrast to the 

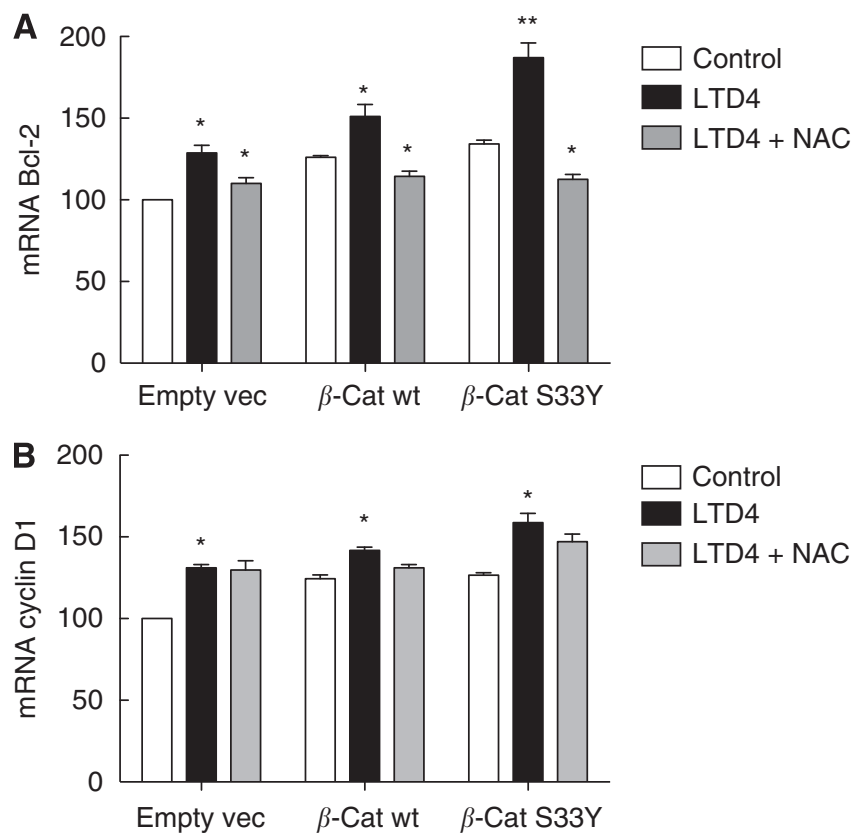

Figure 6 Effects of leukotriene $D_{4}\left(L_{T D}\right)$ stimulation and $\beta$-catenin overexpression on $\mathrm{Bcl}-2$ and Cyclin DI expression. Caco-2 cells were transiently transfected with empty vector (empty vec), HA-wt- $\beta$-catenin ( $\beta$-cat wt), or HA-S33Y- $\beta$-catenin ( $\beta$-cat S33Y). As indicated, the cells were the pre-treated or not with NAC for 15 min before incubation in the absence or presence of $40 \mathrm{nM} \mathrm{LTD} 4$ for $18 \mathrm{~h}$. Levels of Bcl-2 (A), and Cyclin DI (B) messenger RNA (mRNA) in Caco-2 cells, were then measured by quantitative real-time PCR. The expression levels of the genes of interest were normalised to the expression of the reference gene $\beta$-actin and GAPDH. The presented data are given as means \pm s.e. of three separate experiments. $* P<0.05$; $* * 00$.

effects on Bcl-2 expression, the effects on Cyclin D1 expression were independent of ROS formation, as shown by preincubating the cells with the ROS inhibitor NAC (Figure 6B).

\section{DISCUSSION}

We have earlier observed that exposure of Int 407 cells to $\mathrm{LTD}_{4}$ causes translocation of $\beta$-catenin to the mitochondria, and association with the anti-apoptotic protein $\mathrm{Bcl}-2$, thereby enhancing cell survival (Mezhybovska et al, 2006; Paruchuri et al, 2006). Here we suggest a possible mechanism linking $\beta$-catenin to survival signalling in the inflammatory environment. We observed an increase in complex I activity and an increase in ATP/ADP ratio in Int 407 and Caco-2 cells. It is worth mentioning that both Lef-1 and mitochondria transcription factor TFAM1 bears the similar HMG domain that is not only responsible for DNA binding but for protein - protein interaction as well. It has earlier been shown that ATP/ADP ratio is crucial for the decision of the cell's fate (Leist et al, 1997; Richter et al, 1996). Furthermore, Vrbacky et al (2003), showed that a decrease in ATP/ADP ratio in BSC-40 cells is a hallmark of apoptosis. It has been shown in tumour cells (HeLa, MCF-7, and HL-60) that mitochondrial ATP supported increased cellular proliferation rates (Guppy et al, 2002; Sweet and Singh, 1995). In agreement with earlier findings our data strongly indicate that an increase in ATP/ADP ratio favours survival signalling in the cell. Leukotriene $\mathrm{D}_{4}$ increased mitochondrial gene activity in both Int 407 and Caco-2 cells as the activity of the mtDNA encoding for complex I was also increased transiently in both Int 407 cells and Caco-2 cells.
Changes in mitochondria gene activity as well as mutations in the mitochondrial genome are reported for many cancers (Pelicano et al, 2004; Polyak et al, 1998; Waris and Ahsan, 2006). ND2 is overexpressed in human acute myeloid leukaemia cells (Matsunaga et al, 1996). An increased level of $16 \mathrm{~s}$ RNA was shown in polyps of familial polyposis coli patients (Yamamoto et al, 1989). Mutations in $16 \mathrm{~s}$ RNA has been reported for colorectal tumours as well (Polyak et al, 1998). $\beta$-Catenin overexpression in the nontransformed cell line, Int 407, had a dramatic effect on mitochondrial gene activity, but in cancer cells $\beta$-catenin overexpression did not show any significant differences. Caco- 2 cells have higher levels of $\beta$-catenin compared with Int 407 cells and as a result, higher activity of the mitochondrial genome. Therefore, the effect of $\beta$-catenin overexpression on mitochondrial gene activity in Caco- 2 cells was not as prominent as in Int 407 cells.

Reactive oxygen species are formed predominantly through oxidative phosphorylation. Formation of ROS is often increased in cancer in order to maintain cell growth and proliferation (Chen et al, 2007; Chen et al, 1998; Irani et al, 1997). Therefore, it was expected that ROS production would be elevated in this system. We observed increased ROS production in Int 407 cells (but not to the extent of the positive control, $\mathrm{H}_{2} \mathrm{O}_{2}$ ), upon $\mathrm{LTD}_{4}$ stimulation and after $\beta$-catenin overexpression. The cell fate decision for suicide or survival is dependent on signalling pathways activated upon oxidative stress. High doses lead to cell death while a moderate increase favours cell survival signalling (Martindale and Holbrook, 2002). The observed change in ROS was not as significant as in $\mathrm{H}_{2} \mathrm{O}_{2}$ stimulation, leading to the conclusion that a moderate increase in ROS levels in this system mediates survival signalling.

Earlier we showed that $\mathrm{LTD}_{4}$ facilitates survival signalling through both PI-3 kinase/Akt/GSK-3 $\beta$ - and PKC/Erk1/2-dependent mechanisms (Mezhybovska et al, 2006; Paruchuri et al, 2002). Erk activation as a result of oxidant injury was reported in 1996 (Guyton et al, 1996), resulting in cell survival and tumour growth. Akt activation in response to oxidant injury contributes to survival signalling in peroxide-induced apoptosis in a human glioblastoma cell line (Sonoda et al, 1999). Both Erk and Akt signalling has been shown to be upregulated upon $\mathrm{LTD}_{4}$ stimulation in the nontransformed intestinal cell line Int 407 (Mezhybovska et al, 2006; Paruchuri et al, 2002). In the Caco-2 cancer cell line, we observed ROS formation in untreated cells, in which the treatment with $\mathrm{LTD}_{4}$ did not have any additional effect (data not shown). This is not surprising since the elevated levels of ROS have been connected to cancer development for several decades (Pelicano et $a l, 2004)$. It was shown that extracellular addition of $\mathrm{O}_{2}$ resulted in activation of NF- $\kappa \mathrm{B}$, and that this effect was ROS mediated (Cazals et al, 1999; Suzuki et al, 2000). We found an increase in activity of the p65 subunit of NF- $\kappa$ B after LTD $_{4}$ stimulation for $1 \mathrm{~h}$ in Int 407 and Caco-2 cells. Earlier reports from our group did not find any significant effect on NF-kB activation in Int 407 cells after $8 \mathrm{~h}$ or longer stimulation (Bengtsson et al, 2008). Overexpression of wild-type $\beta$-catenin- and $\beta$-catenin-S33Y constructs also activated the p65 subunit of NF- $\kappa$ B. We also checked whether the activation of p65 subunit resulted in its increased activity. We used a luciferase assay to test activity of the p65 response element. The p65 responsive element activity was elevated after $\mathrm{LTD}_{4}$ stimulation as well as after $\beta$-catenin overexpression in both cell lines. There is still some confusion in the literature regarding possible cross-talk of NF- $\kappa \mathrm{B}$ and $\beta$-catenin signalling. $\beta$-Catenin has been reported to regulate NF- $\kappa \mathrm{B}$ in tumour cells (Amit and Ben-Neriah, 2003). Other reports suggest that NF- $\kappa$ B is a regulator of the $\beta$-catenin pathway (Wang et al, 2007), whereas some studies reported that ROS activity is subject to negative feedback regulation by NF- $\kappa \mathrm{B}$ (Bubici et al, 2006). We used the antioxidant (NAC) to validate whether ROS is upstream or downstream of NF$\kappa \mathrm{B}$. p65 activation seems to be ROS mediated as the $\mathrm{LTD}_{4}$ mediated increase in ROS was reduced after antioxidant treatment. We also 
found that the well-known downstream target gene of NF- $\kappa \mathrm{B}$ activity Bcl-2 was induced by $\mathrm{LTD}_{4}$ stimulation or $\beta$-catenin overexpression. These effects were mediated through ROS production, which is in contrast to the effects of $\mathrm{LTD}_{4}$ stimulation and $\beta$-catenin overexpression on $\beta$-catenin/Tcf-mediated Cyclin D1 expression.

In conclusion, we have shown earlier that $\mathrm{LTD}_{4}$ induces $\beta$-catenin translocation to the mitochondria and increases survival by interacting with the cell survival protein Bcl-2. Here we describe for the first time that $\beta$-catenin is involved in signal transduction leading to increased activity of the respiratory chain, which in turn leads to an increased ROS production and as a consequence, NF- $\kappa \mathrm{B}$ activation. NF- $\kappa \mathrm{B}$ is one of the key players in inflammation,

\section{REFERENCES}

Amit S, Ben-Neriah Y (2003) NF-kappaB activation in cancer: a challenge for ubiquitination- and proteasome-based therapeutic approach. Semin Cancer Biol 13: $15-28$

Bengtsson AM, Massoumi R, Sjölander A (2008) Leukotriene D(4) induces AP-1 but not NFkappaB signaling in intestinal epithelial cells. Prostaglandins Other Lipid Mediat 85: $100-106$

Bubici C, Papa S, Dean K, Franzoso G (2006) Mutual cross-talk between reactive oxygen species and nuclear factor-kappa $\mathrm{B}$ : molecular basis and biological significance. Oncogene 25: 6731-6748

Cazals V, Nabeyrat E, Corroyer S, de Keyzer Y, Clement A (1999) Role for NF-kappa B in mediating the effects of hyperoxia on IGF-binding protein 2 promoter activity in lung alveolar epithelial cells. Biochim Biophys Acta 1448: $349-362$

Chen H, Yang S, Yang Z, Ma L, Jiang D, Mao J, Jiao B, Cai Z (2007) Inhibition of GSK-3beta decreases NF-kappaB-dependent gene expression and impairs the rat liver regeneration. J Cell Biochem 102: 1281 - 1289

Chen QM, Bartholomew JC, Campisi J, Acosta M, Reagan JD, Ames BN (1998) Molecular analysis of H2O2-induced senescent-like growth arrest in normal human fibroblasts: p53 and Rb control G1 arrest but not cell replication. Biochem J 332(Pt 1): $43-50$

Clayton DA (1991) Replication and transcription of vertebrate mitochondrial DNA. Annu Rev Cell Biol 7: 453-478

Conacci-Sorrell M, Zhurinsky J, Ben-Ze'ev A (2002) The cadherin-catenin adhesion system in signaling and cancer. J Clin Invest 109: 987-991

Coussens LM, Werb Z (2002) Inflammation and cancer. Nature 420: $860-867$

Cullen DA, Killick R, Leigh PN, Gallo JM (2004) The effect of polyglutamine expansion in the human androgen receptor on its ability to suppress beta-catenin-Tcf/Lef dependent transcription. Neurosci Lett 354: 54-58

Drazen JM (2002) Anti-leukotrienes as novel anti-inflammatory treatments in asthma. Adv Exp Med Biol 507: 217-221

Ekbom A, Helmick C, Zack M, Adami HO (1990) Ulcerative colitis and colorectal cancer. A population-based study. $N$ Engl J Med 323: $1228-1233$

Elstrom RL, Bauer DE, Buzzai M, Karnauskas R, Harris MH, Plas DR, Zhuang H, Cinalli RM, Alavi A, Rudin CM, Thompson CB (2004) Akt stimulates aerobic glycolysis in cancer cells. Cancer Res 64: $3892-3899$

Fridlyand LE, Ma L, Philipson LH (2005) Adenine nucleotide regulation in pancreatic beta-cells: modeling of ATP/ADP-Ca2+ interactions. Am J Physiol Endocrinol Metab 289: E839-E848

Funk CD (2001) Prostaglandins and leukotrienes: advances in eicosanoid biology. Science 294: $1871-1875$

Guppy M, Leedman P, Zu X, Russell V (2002) Contribution by different fuels and metabolic pathways to the total ATP turnover of proliferating MCF-7 breast cancer cells. Biochem J 364: 309-315

Guyton KZ, Gorospe M, Kensler TW, Holbrook NJ (1996) Mitogenactivated protein kinase (MAPK) activation by butylated hydroxytoluene hydroperoxide: implications for cellular survival and tumor promotion. Cancer Res 56: 3480 - 3485

Heise CE, O'Dowd BF, Figueroa DJ, Sawyer N, Nguyen T, Im DS, Stocco R, Bellefeuille JN, Abramovitz M, Cheng R, Williams Jr DL, Zeng Z, Liu Q, Ma L, Clements MK, Coulombe N, Liu Y, Austin CP, George SR, O'Neill GP, Metters KM, Lynch KR, Evans JF (2000) Characterization of the human cysteinyl leukotriene 2 receptor. J Biol Chem 275: $30531-30536$

Henle G, Deinhardt F (1957) The establishment of strains of human cells in tissue culture. I Immunol 79: 54-59 linking chronic inflammation and cancer development. Consequently, the present data add further support to the idea that NF- $\kappa \mathrm{B}$ activation might be crucial for $\mathrm{LTD}_{4}$-induced cell survival.

\section{ACKNOWLEDGEMENTS}

We thank Maria Julias for invaluable to chemical assistance. This work was supported by grants awarded to the authors: AS from the Swedish Cancer Foundation, the Swedish Medical Research Council, the Foundations at Malmö University Hospital, the Julin Foundation, Gunnar Nilsson Foundation, Österlund Foundation, and MM from Royal Physiographic Society in Lund.

Hussain T, Gupta S, Mukhtar H (2003) Cyclooxygenase-2 and prostate carcinogenesis. Cancer Lett 191: 125-135

Irani K, Xia Y, Zweier JL, Sollott SJ, Der CJ, Fearon ER, Sundaresan M, Finkel T, Goldschmidt-Clermont PJ (1997) Mitogenic signaling mediated by oxidants in Ras-transformed fibroblasts. Science 275: $1649-1652$

Kitada M, Koya D, Sugimoto T, Isono M, Araki S, Kashiwagi A, Haneda M (2003) Translocation of glomerular p47phox and p67phox by protein kinase C-beta activation is required for oxidative stress in diabetic nephropathy. Diabetes 52: 2603-2614

Kohli R, Pan X, Malladi P, Wainwright MS, Whitington PF (2007) Mitochondrial reactive oxygen species signal hepatocyte steatosis by regulating the phosphatidylinositol 3-kinase cell survival pathway. J Biol Chem 282: $21327-21336$

Korinek V, Barker N, Morin PJ, van Wichen D, de Weger R, Kinzler KW, Vogelstein B, Clevers H (1997) Constitutive transcriptional activation by a beta-catenin-Tcf complex in APC-/- colon carcinoma. Science 275: $1784-1787$

Leist M, Single B, Castoldi AF, Kuhnle S, Nicotera P (1997) Intracellular adenosine triphosphate (ATP) concentration: a switch in the decision between apoptosis and necrosis. J Exp Med 185: $1481-1486$

Lundin A (2000) Use of firefly luciferase in ATP-related assays of biomass enzymes, and metabolites. Methods Enzymol 305: 346-370

Lynch KR, O’Neill GP, Liu Q, Im DS, Sawyer N, Metters KM, Coulombe N, Abramovitz M, Figueroa DJ, Zeng Z, Connolly BM, Bai C, Austin CP Chateauneuf A, Stocco R, Greig GM, Kargman S, Hooks SB, Hosfield E, Williams Jr DL, Ford-Hutchinson AW, Caskey CT, Evans JF (1999) Characterization of the human cysteinyl leukotriene CysLT1 receptor. Nature 399: $789-793$

Martindale JL, Holbrook NJ (2002) Cellular response to oxidative stress: signaling for suicide and survival. J Cell Physiol 192: 1-15

Matsunaga T, Kudo J, Takahashi K, Dohmen K, Hayashida K, Okamura S, Ishibashi H, Niho Y (1996) Rotenone, a mitochondrial NADH dehydrogenase inhibitor, induces cell surface expression of CD13 and CD38 and apoptosis in HL-60 cells. Leuk Lymphoma 20: 487-494

Mezhybovska M, Wikstrom K, Ohd JF, Sjölander A (2005) Proinflammatory mediator leukotriene D4 induces transcriptional activity of potentially oncogenic genes. Biochem Soc Trans 33: 698-700

Mezhybovska M, Wikstrom K, Ohd JF, Sjölander A (2006) The inflammatory mediator leukotriene D4 induces beta-catenin signaling and its association with antiapoptotic Bcl-2 in intestinal epithelial cells. J Biol Chem 281: 6776-6784

Montoya J, Gaines GL, Attardi G (1983) The pattern of transcription of the human mitochondrial rRNA genes reveals two overlapping transcription units. Cell 34: $151-159$

Nielsen CK, Massoumi R, Sonnerlind M, Sjölander A (2005) Leukotriene D4 activates distinct G-proteins in intestinal epithelial cells to regulate stress fibre formation and to generate intracellular $\mathrm{Ca} 2+$ mobilisation and ERK1/2 activation. Exp Cell Res 302: $31-39$

Ojala D, Montoya J, Attardi G (1981) tRNA punctuation model of RNA processing in human mitochondria. Nature 290: 470-474

Paruchuri S, Broom O, Dib K, Sjölander A (2005) The pro-inflammatory mediator leukotriene D4 induces phosphatidylinositol 3-kinase and Rac-dependent migration of intestinal epithelial cells. J Biol Chem 280 $13538-13544$ 
Paruchuri S, Hallberg B, Juhas M, Larsson C, Sjölander A (2002) Leukotriene $\mathrm{D}(4)$ activates MAPK through a Ras-independent but PKCepsilon-dependent pathway in intestinal epithelial cells. J Cell Sci 115: $1883-1893$

Paruchuri S, Mezhybovska M, Juhas M, Sjölander A (2006) Endogenous production of leukotriene D4 mediates autocrine survival and proliferation via CysLT1 receptor signalling in intestinal epithelial cells. Oncogene 25: $6660-6665$

Pelicano H, Carney D, Huang P (2004) ROS stress in cancer cells and therapeutic implications. Drug Resist Updat 7: 97 -110

Pelicano H, Xu RH, Du M, Feng L, Sasaki R, Carew JS, Hu Y, Ramdas L, Hu L, Keating MJ, Zhang W, Plunkett W, Huang P (2006) Mitochondrial respiration defects in cancer cells cause activation of Akt survival pathway through a redox-mediated mechanism. J Cell Biol 175: 913-923

Polyak K, Li Y, Zhu H, Lengauer C, Willson JK, Markowitz SD, Trush MA, Kinzler KW, Vogelstein B (1998) Somatic mutations of the mitochondrial genome in human colorectal tumours. Nat Genet 20: 291-293

Richter C, Schweizer M, Cossarizza A, Franceschi C (1996) Control of apoptosis by the cellular ATP level. FEBS Lett 378: 107-110

Sarau HM, Ames RS, Chambers J, Ellis C, Elshourbagy N, Foley JJ, Schmidt DB, Muccitelli RM, Jenkins O, Murdock PR, Herrity NC, Halsey W, Sathe G, Muir AI, Nuthulaganti P, Dytko GM, Buckley PT, Wilson S, Bergsma DJ, Hay DW (1999) Identification, molecular cloning, expression, and characterization of a cysteinyl leukotriene receptor. Mol Pharmacol 56: $657-663$

Sheng H, Shao J, Kirkland SC, Isakson P, Coffey RJ, Morrow J, Beauchamp RD, DuBois RN (1997) Inhibition of human colon cancer cell growth by selective inhibition of cyclooxygenase-2. J Clin Invest 99: 2254-2259
Smalley WE, DuBois R (1997) Colorectal cancer and nonsteroidal antiinflammatory drugs. Adv Pharmacol 39: 1-20

Sonoda Y, Watanabe S, Matsumoto Y, Aizu-Yokota E, Kasahara T (1999) FAK is the upstream signal protein of the phosphatidylinositol 3-kinase-Akt survival pathway in hydrogen peroxide-induced apoptosis of a human glioblastoma cell line. J Biol Chem 274: $10566-10570$

Suzuki Y, Nishio K, Takeshita K, Takeuchi O, Watanabe K, Sato N, Naoki K, Kudo H, Aoki T, Yamaguchi K (2000) Effect of steroid on hyperoxiainduced ICAM-1 expression in pulmonary endothelial cells. Am J Physiol Lung Cell Mol Physiol 278: L245-L252

Sweet S, Singh G (1995) Accumulation of human promyelocytic leukemic (HL-60) cells at two energetic cell cycle checkpoints. Cancer Res 55: $5164-5167$

Wang Y, Kreisberg JI, Ghosh PM (2007) Cross-talk between the androgen receptor and the phosphatidylinositol 3-kinase/Akt pathway in prostate cancer. Curr Cancer Drug Targets 7: 591-604

Warburg O (1956) On the origin of cancer cells. Science 123: 309-314

Waris G, Ahsan H (2006) Reactive oxygen species: role in the development of cancer and various chronic conditions. J Carcinog 5: 14

Wikström K, Öhd JF, Sjölander A (2003) Regulation of leukotrienedependent induction of cyclooxygenase-2 and Bcl-2. Biochem Biophys Res Commun 302: $330-335$

Vrbacky M, Krijt J, Drahota Z, Melkova Z (2003) Inhibitory effects of Bcl-2 on mitochondrial respiration. Physiol Res 52: 545-554

Yamamoto A, Horai S, Yuasa Y (1989) Increased level of mitochondrial gene expression in polyps of familial polyposis coli patients. Biochem Biophys Res Commun 159: $1100-1106$ 